\title{
From Finance Capitalism to Financialization: A Cultural and Narrative Perspective on 150 Years of Financial History ${ }^{1}$
}

\author{
PER H. HANSEN
}

In this article I interpret 150 years of financial history with a focus on shifts in the role of finance in society. I argue that over time the role of finance has shifted twice from that of servant to that of master of society, and that this process has been driven by sense making through narratives that legitimized and shaped these changes. When finance became a master rent seeking, cultural capture and out-ofcontrol financial innovation resulted in financial and social instability. Finance as a master was the characteristic of finance capitalism from around 1900-1931 and of financialization from around 1980 to today. Finance capitalism and financialization were enabled by a dominant narrative that legitimized the power of finance. The shifts in the role of finance happened when crises undermined the meaning of the existing narrative and created for a new narrative able to make sense of the crisis and point society in a new direction. This sense-making process stabilized when a new narrative was established that could explain the crisis and legitimize and shape a new role for finance. The article is based on my presidential address presented at the Business History Conference's annual meeting in March 2014 in Frankfurt.

Picking a subject for this presidential address was not easy. There is a tradition that the presidential address contains some autobiographical elements about the speaker, but I have decided not to do that. However, since I will be talking about finance and society, I have

(C) The Author 2014. Published by Oxford University Press on behalf of the Business History Conference. All rights reserved. For permissions, please e-mail: journals.permissions@oup.com

doi:10.1093/es/khu047

Advance Access publication September 5, 2014

Per H. Hansen is a professor in the Department of Management, Politics and Philosophy, Centre for Business History, Copenhagen Business School. Contact information: E-mail: phh.mpp@cbs.dk.

1. I have received helpful suggestions and comments from many people while preparing this address and while turning it into a text. In particular, I would like to thank Anne Magnussen, Alfred Reckendrees, and Dan Wadhwani for invaluable assistance. Needless to say, I alone bear responsibility for the result. 
chosen a topic that I have studied-on and off-since I was an undergraduate student in the mid-1980s. For some odd reason I decided to focus on financial history already in my second year and my bachelor's thesis, my master's thesis and my dissertation all were on financial history. I therefore have the opportunity to build this talk on some of my own research and—not least—on ideas that are very important to me.

I guess you could say that my main concern is about stability and fairness: financial stability and social stability, and not least the link between the two. My concern rises out of a simple, but today often neglected, observation: that between 1945 and the 1970s, the Western world did not experience any financial crises. ${ }^{2}$ This is an important observation because the periods before and after have both been hit by financial crisis with some regularity, and in each period one of these financial crises developed into a serious depression that erased millions of jobs and increased inequality. There was no creative destruction, just destruction.

In addition to being crisis free, the postwar period also saw the rise of a kind of society hitherto unknown to mankind-the social state or the welfare society. During this period, inequality declined considerably for the first time and, together with the related rise of the middle class, this contributed to the social stability and fairness of Western societies. Again, there is an interesting correlation since this period's social and democratic achievements went hand in hand with a new and more rigorous regulation of financial markets that subdued the banker to being a servant of, rather than master of, the economy.

My overall argument or hypothesis in this talk is that when finance gets too dominant a position in society, financial, and social instability follows. In addition, I am going to argue that rather than reduce this development to a matter of economics, it is a cultural process driven or shaped by different, competing narratives.

I cannot prove all this by reference to archival sources or, to say the least, to unanimous agreement in the scholarly literature, of course. But I consider raising such bigger questions the duty of business historians who very often "fly too low over the sources." I realize that some of my points or even my overall approach may be subject to disagreement, but that's how it is, and should be. History and social science are an ongoing conversation, not really about proving anything. I am going to address some perennial issues in economic and

2. Of course, this statement depends on the definitions of a financial crisis. While I see the point in Anna Schwartz' definition in Schwartz, "Real and Pseudo Financial Crises," I find the one in Eichengreen and Portes, "The Anatomy of Financial Crises" to be more adequate and useful. In both cases, a financial crisis must involve the banking system. 
business history such as continuity and change, power, inequality, and most important, the shifting role of finance in society. But first, I am going to say a few words about my take on the historian's craft and on culture.

\section{History and Culture ${ }^{3}$}

Historians, including business historians, do not occupy a privileged, neutral observation point from which to observe the past or the present in an objective way. Quite the contrary, what we do-teach, doing research and write-is not truth seeking but part of an ongoing conversation with colleagues in and outside our field and (hopefully) also with society at large. From my perspective, there is no such thing as objectivity because our perception and worldview is shaped by language and culture.

The idea of history as a truth-seeking discipline comes from the nineteenth century, where the ideal was for social science and the humanities to catch up with the natural sciences. The view that we should write history in accordance with Leopold von Ranke's ideal "wie es eigentlich gewesen" still holds a strong spell over many practitioners in our field. This idea has every once in a while led to an extreme focus on the archive and primary sources as the thing that constitutes our field. This is what Ludmilla Jordanova has called "the cult of the archive." 4

In my opinion, the so-called historical methodology of source criticism has developed into a strait jacket that constrains our choice of topics and the questions we ask. ${ }^{5}$ It forces us to fly too low over the sources and keep us from asking larger and much more interesting questions that cannot be answered by direct reference to archival sources alone. In order for us to get out of that strait jacket, we need to begin with the research question and to use relevant theories and hypotheses in our work. We must ask larger questions that address issues of concern in contemporary societies, issues such as power, inequality, and financialization.

3. For my view on business history and culture, see Hansen, "Business History: A Cultural and Narrative Approach."

4. Jordanova, History in Practice.

5. I believe that the focus on source criticism is particularly strong and dogmatic in the Danish historical tradition, but the "cult of the archive" is, I would argue, strong among historians internationally. For a discussion of Danish source criticism, see Nevers, "The Magic of Source-Criticism.” For discussions of historical methods for business historians, see the many interesting essays in Bucheli and Wadhwani, eds., Organizations in Time. 
This can be done in many ways, of course. In my own work, I have become more and more convinced that it is important to follow and analyze the narratives that contemporary actors lived by, created, and circulated. The interesting thing about narratives-the ones we study as well as those we produce-is that they are performative. ${ }^{6}$ This means that narratives co-construct and legitimize social reality. Narratives create order out of chaos by assigning meaning and causality to seemingly incomprehensible and unconnected events; and in doing so, they shape our perception, worldviews, decisions, and actions. This is the reason that economic and financial developments and changes are largely cultural.

If we want to understand power, we must analyze the narratives that shape, legitimize, and promote that power, as well as the counternarratives that struggle to be heard. As business historians we have an obligation to examine and be critical of power in the world of business and finance. Perhaps it is our finest-but also somewhat neglected-calling.

So what about culture? My view of the world is that of a socially constructed social reality. For that reason, I see the world as constituted through meaning assignment, which is a cultural process specific to time and space. Culture is a contextually specific blueprint for how we see the world and how we act. The anthropologist Grant McCracken has put it this way:

Acting in conformity with the blueprint of culture, the members of a community are constantly realizing the categories in the world. Individuals continually play out categorical distinctions, so that the world they create is made consistent with the world they imagine. In a sense, the members of a culture are constantly engaged in the construction—the constitution—of the world they live in. ${ }^{7}$

This approach has enormous consequences for the study of finance, also in a historical perspective. Gillian Tett, who has the advantage of being both a social anthropologist and a Financial Times editor with a deep understanding of financial markets has argued that

bankers like to imagine that money and the profit motive is as universal as gravity. They think it's basically a given and they think it's completely apersonal. And it's not. What they do in finance is all about culture and interaction. ${ }^{8}$

6. For a discussion of performativity in economics, see Mackenzie, An Engine, Not a Camera, 15-25. A great example of the performativity of narratives is Ho, Liquidated.

7. McCracken, "Culture and Consumption."

8. Barton, "On the Money." See also Tett, Fool's Gold. 
Unfortunately, one could substitute economists or even business historians for bankers and the quote would still make sense. However, if we want to get a better understanding of how financial markets work, we should take much more notice of the interesting research going on in social and cultural studies of finance. For instance, the anthropologist Karen Ho has argued that Wall Street investment bankers have shaped the world in their own image or according to their own narrative. The idea of shareholder value is not a universal one; it is a narrative shaped by private interests and made possible by scholarly legitimization and the breakdown of the social narrative in the 1970s. ${ }^{9}$

However, the fact that sociologists and anthropologists are doing important and interesting work does not mean that business historians have nothing to bring to the table. On the contrary, I would like to suggest that, beyond the historical perspective, our strength lies in our commitment to empirical work and extensive contextualization or perhaps it would make more sense to term it our ability and ambition-on a good day-to connect the micro level with the macro level. Together with our attention to change and historical specificity, these strengths offer a significant contribution to and enrichment of other social sciences' understanding of finance. ${ }^{10}$

\section{Finance, Financial Stability, and Narratives}

As mentioned, my concern here is particularly with finance, and my overall argument can be summarized like this. When finance becomes dominant in the shape of finance capitalism (early twentieth century) or financialization (late twentieth and early twenty-first century), it grows out of control and shapes the world in its own image by enacting and circulating a specific narrative. Financial motives and objectives become prevalent as a result of cultural capture, framing, and practices performed by powerful vested interests. Historically, when finance dominates, rent seeking and financial instability follows, and "New Era" narratives lead to financial and social instability in the shape of credit-based bubbles and financial crises.

This process or dynamic is largely a cultural one shaped by narratives that make sense of and legitimize the rise of finance and frame our perception to that effect. During crises, there is a loss of meaning

9. See for instance, Ho, Liquidated; and Ho, "Disciplining Investment Bankers"; Zaloom, Out of the Pits; Abolafia, Making Markets; Preda, Framing Finance; and Mackenzie, An Engine, Not a Camera. More generally on sociology of finance, see Cetina and Preda, The Oxford Handbook of the Sociology of Finance.

10. See Hansen and Wadhwani, "Can Business History and Anthropology Learn from Each Other?"; Hansen, "Business History: A Cultural and Narrative Approach." 
because the dominant narrative can no longer make sense of and explain events. This loss of meaning leads to intensified narrative conflict; and the sense-making process is only stabilized when one contending narrative becomes dominant. As historians we are part of this sense-making process too, and our narratives are performative as well; if anyone reads them, anyway. Historically, the dominant narrative has constructed and legitimized finance as either master or servant of the economy and society; and this has happened in the larger context of the grand narratives of the Keynesian or social state and liberalism, respectively.

Not coincidentally, these grand narratives include the two main approaches to financial instability and financial crises. The first approach emphasizes that capitalist market economies have a built-in tendency to instability. This theory has been most strongly promoted by Hyman Minsky and his Financial Instability Hypothesis. Other proponents are Irving Fisher and his debt-deflation theory of great depressions, and Charles Kindleberger's empirically based history of financial crises. More generally, this narrative is related to the theory of John Maynard Keynes, whereby the economy is not always able to create equilibrium by itself. ${ }^{11}$

This story emphasizes the "animal spirits" of human actors that may lead to a "social epidemic" resulting in a debt-financed bubble and financial crisis. ${ }^{12}$ I have argued that a financial bubble is essentially a cultural process driven by the need for making sense of the world through narratives. ${ }^{13}$ The implication of this first Keynesian narrative is that state intervention in the economy is necessary in order to constrain the financial system and its ability and incentives to create credit and financial innovations.

On the other hand, a different approach states that the market economy creates equilibrium by itself unless distorted by harmful state or central bank intervention. The foundation of this story is neoclassical economics with its emphasis on atomistic, rational utility optimizing actors (known as Homo Oeconomicus) operating on perfect markets. This narrative has been promoted by monetarists, andwith some variation-Austrian school economists. ${ }^{14}$

11. See Minsky, “A Theory of Systemic Fragility”; Fisher, “The Debt-Deflation Theory of Great Depressions”; and Kindleberger and Aliber, Manias, Panics and Crashes.

12. See Akerlof and Shiller, Animal Spirits, and Shiller, "The Sickness beneath the Slump."

13. Hansen, "Making Sense of Financial Crisis and Scandal."

14. For the monetarist view, see Friedman and Schwartz, A Monetary History of the United States, and Schwartz, "Real and Pseudo Financial Crises." For the "Austrian” view, see White, "How Did We Get into This Financial Mess?" 
This neo-classical narrative of an economy in perfect balance as long as states and central banks do not interfere has had a profound influence on Modern Finance. The Efficient Market Hypothesis and the model-building propensity of Modern Finance have left us with an unsustainable belief in markets. ${ }^{15}$ However, if one accepts the neo-classical and Modern Finance story, the implication will be that markets must be left to their own devices in order to maintain financial stability. This was the belief of many influential actors up to the 2007-2008 financial crisis-a nice illustration of how narratives shape world views.

It should be clear that the Keynesian and neo-classical narratives are opposites. One cannot agree with both at the same time, and as already argued, they have very different implications. These two narratives are also inextricably linked to the two grand opposing narratives, the welfare or social state (Keynesian) narrative and the narrative of economic liberalism, that are engaged in a constant struggle about how to make sense of and explain the world.

With respect to the overall role of the financial system in the economy and in society, there are equally opposing stories that are related to the grand narratives already mentioned. The first is from Joseph A. Schumpeter, who in his book Theorie der Wirtschaftslichen Entwicklung from 1912 portrayed the banker as a middleman who stood "between those who wish to form new combinations and the possessors of productive means. He is essentially a phenomenon of development ..."16

In Schumpeter's story, the banker was a helper or servant who assisted the entrepreneur (the hero), who carried out the innovations that made economic development happen. However, at approximately the same time as Schumpeter's book appeared, another Austrian completed a book with a more sinister view of the banker and his instrument, the bank. In 1910, Rudolf Hilferding published Das Finanzkapital, in which he argued that Austrian and German banks had become "masters" of industrial capital. Through interlocking directorates and corporate ownership, banks had amassed too much economic and political power. ${ }^{17}$

The two narratives represented here by Schumpeter and Hilferding fit quite well with Alexander Gerschenkron's "backwardness" hypothesis, where the degree of national backwardness determined the level of bank involvement in industrialization. ${ }^{18}$ This also implies

15. For discussions of the efficient market hypothesis, see Mackenzie, An Engine, Not a Camera, and Fox, The Myth of the Rational Market.

16. The quote is from the English edition: Schumpeter, The Theory of Economic Development, 74 .

17. Hilferding, Finance Capital, 364-70 and passim.

18. Gerschenkron, Economic Backwardness in Historical Perspective. 
a distinction between the Anglo-Saxon market-based financial system and a continental bank-based system where universal banks played a significant role. However, in terms of bank power, the distinction may have been exaggerated. Hilferding clearly saw similarities between the continental and the US financial systems and found that his term "finance capital" could be applied to both. ${ }^{19}$

While there may be minor disagreement with respect to the exact years, I am going to use a periodization that I consider quite uncontroversial. The period spans about 150 years and it covers a time span during which the Western world went from an increasingly international or even global economy (1850-1931) to societies characterized by state intervention on many levels (1931-1970s), and then to a situation where neo-liberalism paved the way for a new wave of globalization (1970s).

These three periods correspond very well, of course, to the two distinct narratives that I have presented previously where the role of the state and the belief in free markets are the most important signifiers. Moreover, they also neatly characterize the context within which the financial industry worked and developed, most notably one of increasing globalization from 1870 to 1931 and again from 1980 to today. ${ }^{20}$ In the following, I will mainly draw on examples from the financial sector in Denmark, but I will also refer to the US financial system, where Wall Street was both an important international financial center and a principal metaphor for finance. In the next sections, I look at the three periods before 1931, from 1931 to the 1970s and, finally, from the 1970s to this day. Finally, I discuss the consequences of financialization in a little more detail.

\section{Globalization 1.0: Economic Liberalism, 1850-1931}

The period from 1850 to 1931 period characterized by an increasing adherence to the doctrine of economic laissez faire. This was the way most people or people with any power saw the world. Markets free from state interference came to be considered a natural thing, even though they were, of course, cultural constructs, not given by God or by nature. Except for securing property rights and a few other obligations, the state was supposed to play a minimal role in the economy, and in many countries, this doctrine extended to the financial sector; even more so in Denmark than in most other countries. While Danish savings banks were regulated from 1880, the first regulations

19. Hilferding, Finance Capital, 307.

20. For an overview of financial history in this period, see Grossman, Unsettled Account. 
for joint stock companies and commercial banks were passed in 1917 and 1919, respectively. ${ }^{21}$

The period from 1850 to 1931 was the era in which globalization and finance capitalism developed, and especially in the decades after 1900. Private initiative abounded and like many other countries Denmark industrialized with the assistance from financial institutions. In my masters' thesis from 1989, I examined the role of a provincial commercial bank in promoting economic development. The Discount Bank of Funen, established in 1846, quickly took on all the functions of a universal bank-promoting local business development by lending, underwriting loans, and share issues, etc. ${ }^{22}$

The bank's energetic manager Lorenz Bierfreund was not risk averse; and during his reign, the bank experienced its share of financial crises and panics. The first one was in 1857, the next in 18751878 , and the third in 1885 . The most severe was in the 1870s, where Bierfreund was criticized at the shareholders' meeting for taking too large risks. Bierfreund's reply was that the bank

has the obligation-besides making money, of course-to further monetary exchange and to promote commerce and industry in the region. If I ask whether the Discount Bank of Funen has fulfilled this obligation, no one, I believe, can deny that it has. ${ }^{23}$

Of course, Bierfreund said this to defend himself from criticism. However, the statement also demonstrates that he saw the bank's purpose as much broader than the creation of shareholder value. Despite the criticism against him, the fact that Bierfreund could draw on this narrative about economic development, which went all the way back to the bank's establishment in 1846, shows that it was an acceptable point of view at the time. It is hard to imagine a present day CEO of a bank defending his actions by arguing that even though he lost a lot of the shareholders' money, he did good deeds for society. It is an example of the Schumpeterian "banker as servant" narrative.

Though this narrative was not undisputed, it was clearly a legitimate way to perceive and frame the role of banks. Others, such as C.F. Tietgen, the CEO of Privatbanken, a larger bank located in Copenhagen, were more cynical and promoted the shareholder value narrative from an early date. However, overall the narrative about

21. Hansen, "From Growth to Crisis," and Hansen, "Bank Regulation in Denmark from 1880 to World War II."

22. Hansen, "Fyens Disconto Kasse, 1846-1886; Hansen, "Fyens Disconto Kasse, 1846-86. indlån og udlån”; Hansen, "En højst ubehagelig situation”; and Hansen, "Banker og økonomisk udvikling.

23. Hansen, "Banker og økonomisk udvikling." 
banks and bankers was one of their contributions to the economic development of Danish society.

In the early twentieth century, competing narratives developed between industrial and agricultural interests in Denmark, and in 1912, Alexander Foss, an industrialist and founder of the Industrial Council gave a talk on "Denmark as an industrial country." 24 There Foss argued that the future of Denmark lay with industry rather than agriculture. This story was strongly disputed by agricultural interests but was supported by many banks, first and foremost the Landmandsbanken. Ironically, Landmandsbanken meant the Farmers' Bank, but after its establishment in 1871, it quickly developed into a universal bank with close relations to Denmark's largest industrial companies.

The same was true for C.F. Tietgen's Privatbanken, but Landmandsbanken and its CEO from 1910, Emil Glückstadt, took the lead in the Danish financial industry. Glückstadt amassed considerable power-for instance through his position as board member on more than 20 non-financial companies. ${ }^{25}$ The narrative of industrial progress assisted by the banks was crystallized in public representations of Emil Glückstadt. For instance, one early portrait of him, probably from around the time of World War I, argued that

Emil Glückstadt, Landmandsbanken's young, brilliant CEO is indisputably one of the men who have taken the lead in the development of the financial, economic and mercantile areas. There are only a few new corporations, who do not to a larger or lesser degree, rely on his insightful assistance. ${ }^{26}$

This narrative fits quite well with Schumpeter's idea of the banker as a servant to the economy. However, change was under way. World War I and the institutional shifts that came with it seemed to turn the narrative toward a much stronger focus on easy gains on the stock exchange or from new business opportunities due to the war. One sign of this change could be seen in the view of the stock market. For instance, during and after the war, the stockbroker Alfred Horwitz wrote a number of articles for Danish newspapers where he criticized the bubble mentality of the public-a herding behavior that Keynes would call the animal spirits, and Robert Shiller a social epidemic. In 1917, for instance, Horwitz wrote that

there is gambling everywhere ... on the racecourse, at the art auctions, with properties, on the stock exchange! No one seems to

24. Foss, "Danmark som industriland."

25. For more on Glückstadt and Landmandsbanken, see Hansen, "Making Sense of Financial Crisis and Scandal."

26. Ibid; 683. 
remember that the stock exchange once was-and never should have been anything else-than the center of commercial life, the heart chamber of the money market, the heart rate of which started the organism of business life. The inclination to make as much money as possible in as short time as possible-and preferably without doing any work-has led to the concept [of the minute-millionaires]. ${ }^{27}$

Horwitz leaves no doubt that financial thinking and motives were gaining ground during the war, and other contemporary articles and cartoons confirm this perception. At the same time, and clearly related, criticism arose of the banking industry in general and of Landmandsbanken in particular. In 1919, one of the most critical observers, professor of economics at the University of Copenhagen and member of the Danish parliament, Lauritz V. Birck argued in Parliament that the banks had become too powerful and dominated the large Danish companies. In a book published in 1928, he continued this narrative, arguing that

the bank becomes the center for high-finance's action and power ... Through the bank high-finance struggles for the economic power over the nation, even for the political power. The banking industry has become the 'third power' ... ${ }^{28}$

Birck also criticized the practice of interlocking directorates, and in general, his narrative about the overwhelming power of finance corresponded well with Hilferding's narrative of finance capital. In the United States, the financial system with J.P. Morgan in front was also under attack from critics such as Louis D. Brandeis, and the Pujo Committee, who constructed narratives along the same lines. ${ }^{29}$

This shift from a positive to a negative narrative about the financial system and the corresponding rise of the finance capitalism story was clearly a widespread phenomenon that gained influence in the 1910s and 1920s. Whether actual practices changed is not necessarily certain, but the new narrative was performative and shaped the view of banks. It paved the way for the finance capitalism narrative to become the new dominant story about finance.

The financial crises in 1907-1908 and again in the interwar period as well as the many institutional changes brought on by World War

27. Horwitz, Minut-Millionærer.

28. Birck, Under Højkapitalismen, and Birck, Verdenskrisen Og Danmark.

29. Brandeis, Other People's Money. For the Pujo Committee's report, "Money Trust Investigation: Investigation of Financial and Monetary Conditions in the United States Under House Resolutions Nos. 429 and 504," see http://fraser.stlouisfed.org/publication/?pid=80. Accessed July 16, 2014. 
I no doubt contributed to the increasingly negative view of finance. In Denmark, Landmandsbanken, the largest bank in Scandinavia, had expanded dramatically during and after the war, and in the early 1920s, the bubble burst. Landmandsbanken failed in 1922. In February 1923, the Parliament guaranteed all the bank's liabilities, and in 1928 the state became the sole owner of the bank. It was not until the 1950s that ownership of the bank was again fully private. ${ }^{30}$

Throughout the 1920s and into the early 1930s, the Danish banking system was in crisis. In October 1929, Wall Street crashed, and in the following years, banks in Austria, Germany, and the United States among other places failed together with the gold standard. The gold standard narrative or mentalité, as Barry Eichengreen and Peter Temin have called it, was instrumental in legitimizing the deflationary policy—or austerity as we would call it today-that made the great depression great. $^{31}$

In most countries, including Denmark and the United States, investigations of financial practices and the causes of bank failures were the next step. The purpose was to make sense of the crises. In Denmark, the committee focused on Landmandsbanken's failure and the report published in 1924 concluded that Emil Glückstadt and his co-manager Ove Ringberg had exposed the bank to too much risk and to overexpansion. In the span of a relatively few years, banks and bankers had gone from being well-reputed servants to the status of masters of the economy and, by implication, villains.

In the United States, the Pecora Report from 1934 symbolized the same transformation of bankers from being highly respected individuals to villains who had not worked to serve the economy but profited from conflicts of interests and enriched themselves while exposing the financial system to excessive risk and instability. The fact that a business scandal such as the Kreuger crash seemed to be part of the system as well did nothing to moderate the narrative. ${ }^{32}$

There were alternative or competing stories, however. For instance in Denmark, professor of economics Axel Nielsen, argued that the primary reason for the financial crisis was the central bank's expansionary monetary policy. While Nielsen thus echoed present day's monetarists and Austrian school economists, the Social Democrats argued that the crisis was a system failure: "The story of capitalism's terrifying crimes against the Danish people." This example shows

30. Hansen, På Glidebanen Til Den Bitre Ende.

31. Eichengreen and Temin, "Fetters of Gold and Paper." See also Eichengreen, Golden Fetters.

32. "The Pecora Report." For the Kreuger crash, see Jones and Vargas, "Ivar Kreuger and the Swedish Match Empire," and Partnoy, The Match King. 
that wherever there is a dominant narrative, there are counter-narratives that compete about making sense of the events. ${ }^{33}$

Nonetheless, the finance capitalism narratives about greedy and risk-prone bankers serving their own interests rather than those of society won the day. The narratives that rose out of investigations such as these not only paved the way for and legitimized new regulatory and institutional initiatives; they also made a new kind of society possible. In Denmark, a new bank act was voted through parliament in 1930, and in the United States, the Glass Steagall bill and the Securities Exchange Act were enacted in 1933 and 1934, respectively, in the midst of the Great Depression. The age of laissez faire capitalism was over, the New Deal and a new grand narrative was under way.

\section{The Social—Welfare-State, 1945-1970s}

In his aptly titled book The death of the banker, Ron Chernow neatly describes the changing perception and narrative of the banker from the era of laissez faire finance capitalism to the era of the social state. ${ }^{34}$ What paved the way for these profound changes was first and foremost a cultural process. The way people made sense of the world changed dramatically and a new narrative was constructed that soon came to be legitimized by John Maynard Keynes' pathbreaking book, The general theory of employment, interest and money. ${ }^{35}$

In turn, the new grand narrative legitimized the rise of the social state and the relative suppression of globalization and finance including capital movements. Again, this dramatic change was first and foremost a cultural change enabled and shaped by the rise of a new grand narrative that offered a different way to make sense of and see the world. From this perspective, the economy is not a system outside of the cultural blueprint and the cultural context.

In short, this narrative explained the world differently than the neo-classical narrative. The depression, the unemployed, the empty production plants, the lack of investment, and the despair were not caused by government and central bank intervention in the economy or by labor unions and sticky wages. There was a deep loss of meaning that could not be explained by the neo-classical narrative. The problem was the inability of the economic system to establish equilibrium, and the remedy was government and central bank intervention. The new Keynesian narrative made sense of it all.

33. Hansen, "Making Sense of Financial Crisis and Scandal."

34. Chernow, The Death of the Banker.

35. Keynes, The General Theory of Employment, Interest and Money. 
After World War II, this new narrative came to dominance in Western societies. The moral was that never again should a situation like this be allowed to develop. Societies had to offer a new narrative to the people who had suffered through depression and war. From the Danish Social Democratic Party's new program the Future Denmark from 1945, the Beveridge report Full Employment in a Free Society in the United Kingdom, and Ludwig Erhard's Soziale Marktwirtschaft to Alvin Hansen's promotion of Keynesian economics and Johnson's Great Society in the United States, a new narrative crystallized and made new policies possible. It was the narrative of the welfare state. It was, so to speak, payback time for ordinary people, who had suffered the most during the depression and two devastating wars. And just to make sure that the incentive was properly understood, the fact that the Soviet Union now represented an alternative (if not appealing) narrative did not reduce the wish of the privileged groups to include ordinary people in the American or the Danish dream.

While governments assumed more responsibility for the well-being of ordinary citizens than ever before, economic growth and development had to be promoted in order to pay for the efforts. Focus shifted from finance to the "real economy" and increases in productivity that could pay for the rising living standards and the increased access for everyone to health and education. Barry Eichengreen has argued that the golden age of economic growth Europe experienced in the postwar period was based on a kind of agreement between capital and labor that the first reinvested profits and the latter held back on wage claims. ${ }^{36}$

Whether this hypothesis is warranted or not, it seems to me that it exemplifies a bigger claim, namely that during the postwar period there was a certain idea of the nation as a community even if only an imagined community. ${ }^{37}$ What kept the nation together was the narrative of the social state, a narrative that gradually lost its coherence from around 1980 when neo-liberalism, financialization, individualism and the competition state began to take over.

One can look many places to search for expressions of the social state and the nation as a community. One such place is Hollywood. In It's a wonderful life from 1946, James Stewart plays George Bailey who is trying to save his Building and Loan association from the evil capitalist Mr. Potter who is only interested in money. Needless to say, in the end George wins, but only with help from the community. The film takes place in the midst of the Great Depression, and thus signals a farewell to the period of finance capitalism. ${ }^{38}$

36. Eichengreen, "Mainsprings of Economic Recovery in Post-War Europe," and Eichengreen, The European Economy since 1945.

37. Anderson, Imagined Communities.

38. Capra, "It's a Wonderful Life." 
A number of films recorded in the 1950s portray the development of American capitalism and the change from finance capitalism to corporate and managerial America and the organization man. It may be a boring, conformist life, but at least it was a better life with the prospect of owning a house and a car and the chance "to arrive" by climbing the social ladder. ${ }^{39}$ Quite often, the same imagined community such as a town or the nation is an important background for films such as the Man in the gray flannel suit, Executive Suite, and the Apartment. ${ }^{40}$

It's a wonderful life also portrays, I believe, an important characteristic of the different paths that capitalism could take. One path was the finance capitalism and shareholder value focused one represented by Mr. Potter, who is not only lonesome but also sits in a wheel chair and does not have a lot of fun, except for counting his money. The other path was a more local, community-oriented one with George Bailey who comes to realize that he is needed in the town of Bedford Falls. Again, these were two very different narratives; and for a number of years in the postwar period, it seemed like the community-based story might actually stand a chance-not only in the United States, but even more so in Denmark.

After World War II, banking became transformed in the United States, Denmark, and the rest of Europe. In Denmark, the reconstructed Landmandsbanken, along with other banks, became highly risk averse because of the interwar crisis, and built up hidden reserves to an extent that the bank supervisory authority criticized this practice in strong terms. ${ }^{41}$ In most countries, the financial system was now thoroughly regulated and segmented, as were capital movements. The financial system consisted of two different tracks: commercial banks with shareholders and a more community-based track of member-owned savings banks and/or cooperative banks. In Denmark, savings banks could be seen as part of the cooperative movement with its own narrative and which played quite an important role in the Danish economy. ${ }^{42}$ Until 1913, total savings bank assets were bigger than commercial bank assets and even though bank assets grew fast during and after World War I, the financial crisis of the 1920s meant that the public turned to the savings banks once again.

Commercial banks and savings banks were essentially based on completely different narratives and cultures, and they therefore

39. McCracken, "When Cars Could Fly."

40. Johnson, "The Man in the Gray Flannel Suit”; Wise, "Executive Suite”; and Wilder, "The Apartment."

41. Hansen and Mørch, Den Danske Bank.

42. Mordhorst, "Arla and Danish National Identity." See also Mordhorst, "From Counterfactual History to Counter-Narrative History." 
appealed to different groups of stakeholders. This seemed to work fine, but over time, the savings banks came under pressure, due to the changing composition of the Danish economy and regulatory constraints that kept them from certain lines of business. The ambitions of some savings bank managers probably mattered as well, and in the late 1960s, the Danish Savings Bank Association started lobbying for an easing of the Savings Bank Act. When nothing happened, a midsize savings bank decided to act on its own, and in January 1973, it announced that it was merging with one of the country's largest commercial banks, Privatbanken-in many people's mind, the capitalist bank par excellence.

The merger therefore was not only a merger between two financial institutions. Much more important, it was also a merger of two opposing narratives, and that caused trouble. The announcement was received with hostility not only among the savings banks but also in the public and the media. Accusations that (evil) capitalists were taking over ordinary people's savings institutions put pressure on the management. Despite the fact that the merger made sense in economic and strategic terms, the public outcry forced the savings bank's management to make a U-turn and ask to be released from the agreement they had already signed. ${ }^{43}$

This incident can only be explained in cultural and narrative terms, not economic. The conflict was a semantic struggle between two narratives that had also fostered very different cultures in the commercial banks and savings banks, respectively. Interestingly, the conflict became the catalyst for the first case of deregulation of the financial industry in Denmark, since only one year later, in 1974, the parliament passed a new Bank and Savings Bank Act that gave commercial and savings banks the same legal footing except for ownership.

This example of deregulation was just one sign that the world was about to change dramatically, once again. In 1972, the Bretton Woods agreement from 1944 broke down as a result of diverging balance of payment deficits and exchange rates, and different underlying national worldviews. More generally, the trust in Keynesian demand management and managerial capitalism ran into severe trouble with the 1973 oil shock and the so-called stagflation crisis. Like in the 1930s, there was a loss of meaning that the Keynesian narrative could not explain. Thus, during the 1970s, a neo-liberal turn-around began to manifest itself resulting in a new focus on free markets and shareholder value. The Western world was about to enter a new grand narrative.

43. Hansen, "Organizational Culture and Organizational Change," and Hansen, "The Danish Savings Banks Association and the Deregulation of the Savings Banks, 1965-1975." 
Globalization 2.0: The Rise of Neo-liberalism and the Competition State

Perhaps the cultural foundation of the shift in economic ideology from the social state to the competition state can best be illustrated by yet another example from Danish financial history. Following the new 1975 Bank and Savings Bank act, savings banks were allowed to conduct the same business operations as commercial banks. The largest savings banks in particular soon began to make use of these new business opportunities, and the result was that the collectively owned Fællesbanken (the common bank) became superfluous. Fællesbanken was a commercial bank established by the savings banks in 1949 in order to carry out business operations that the Savings Bank act of 1937 had prohibited.

After the Bank and Savings Bank act was passed in 1974, the need for Fællesbanken was reduced, especially for the biggest savings banks. In the early 1980s, two large savings banks therefore made an offer to buy the bank and split it between them. Again, the savings banks movement rallied against this move, labeling the offer a hostile takeover attempt by savings banks whose CEO's were not "real savings bankers." The attempt to buy Fællesbanken was called off, and instead it was sold to Denmark's largest insurance company, Hafnia, in $1985 .{ }^{44}$

In Hafnia a young, dynamic CEO, Per Villum Hansen, had great plans. At the time of buying, Fællesbanken insurance companies were not allowed to do banking business. Yet, by setting up a holding company that owned both the bank and the insurance company, Hansen had in effect created the first Danish financial supermarket since the interwar period. Still, Villum Hansen was not done. He was about to introduce the "hostile takeover" to the Danish business community and public. It was a practice he had learned in the United States, of course. With his new financial muscle and a reputation to die for, Villum Hansen set out to buy his biggest competitor the insurance company Baltica. The attempt was launched in 1990, and quickly developed into a siege, where Denmark's largest bank Danske Bank (until 1976 Landmandsbanken), financed both the attacker and the attacked.

To make a long story short, both Hafnia and Baltica went bankrupt in the financial crisis that hit Scandinavia in the early 1990s. This case was a sign of just how much the world had changed since the early 1970s. A further significant sign of cultural change was the fact that in late 1988, the Danish Savings Bank Association managed to

44. This story is told in Hansen, Da sparekasserne mistede deres uskyld. 
lobby its way to a new law that made it legal for savings banks to turn themselves into publicly owned joint stock companies. Until then, the ownership structure had been the only remaining formal difference between commercial banks and savings banks. With that difference out of the way, it took only one year before Denmark's largest savings bank, the largest cooperative bank and Privatbanken merged into Unibank, which became part of Nordea in 2000.

The interesting thing about this merger is that it signified the symbolic convergence of the two tracks and two narratives in Danish capitalism in the twentieth century. While significant protests had managed to stop the merger of a savings bank and Privatbanken in 1973, this time around no one lifted an eyebrow. The merger was seen as logical and the right thing to do. At the same time, Danske Bank took over two other large banks, and the bank's top-managers Knud Sørensen and Tage Andersen, who the public nicknamed Black Knud and Cold Tage, respectively, were celebrated as the heroes of the emerging financialized economy, where banks utilized both economies of scale and scope-i.e., introducing ever bigger banks now as financial supermarkets. ${ }^{45}$

These incidents are telling examples of just how deep a cultural change the Danish society had undergone since the postwar period. In the 1950s and 1960s, politicians were the heroes who, with support from business and labor unions, were expected and relied upon to create the good society and make sure that the state took care of everybody in a country where, as the Danish priest and poet N.F.S. Grundtvig wrote as early as 1820, "few have too much, and even fewer too little." This narrative of an egalitarian Denmark fits very well with the social state that was built in the postwar period.

However, the egalitarian narrative came under increasing pressure as the neo-liberal grand narrative gradually replaced the social state narrative from the 1970s. Focus shifted from politicians as heroes to top-managers in business and finance who became the new heroes or masters. Where managers had been helpers or servants in the social state, the roles were turned around in the neo-liberal, financialized state narrative. Top-managers became the new heroes who should increase the size of the pie, while politicians were reduced to servants obliged to arrange for an institutional framework that constantly reduced constraints on business and finance. At the same time, a perhaps overly cynical view of politicians as egoistic, vote-optimizing individuals interested only in their own careers developed in the shape of public choice theory. One needs only to watch House of cards to realize what that means culturally.

45. Hansen, "Organizational Culture and Organizational Change"; Hansen, $D a$ sparekasserne mistede deres uskyld," and Hansen and Mørch, Den Danske Bank. 
Making CEO's the new heroes was also a necessary condition for the explosion in executive compensation. Because of the power of narratives, most people came to accept the idea that the CEO mattered enough for the company to be extremely well compensated. Well, even the word "compensated" is problematic because it implies a fair exchange of something for something. This situation could (and can) only be maintained because the nation developed into a trivial abstraction for business leaders in a globalized world. What mattered were lower taxes and subsidies, while the former social states became engaged in a race to the bottom. Welcome to the competition state.

In the field of social science-including economics-these dramatic cultural and ideological changes were legitimized and furthered by scholarship that acted as pillars of the neo-liberal or monetarist and shareholder value narrative.$^{46}$ Scholarship from Milton Friedman and George Stigler among others on the macro level and by Jensen \& Meckling and Jensen \& Murphy at the micro level made sense of the stagflation crisis and legitimized and paved the way for deregulation, privatization, and tax cuts that found their first political expressions in the election of Margaret Thatcher in the United Kingdom in 1979 and Ronald Reagan in the United States in $1980 .{ }^{47}$

In his inaugural address on January 20, 1981, Reagan famously said that "government is not the solution to our problem; government is the problem," and thus he presented the new narrative in a nutshell. It was a slow development, to be sure, but it had not happened without this new narrative that helped actors make sense of the world in a new way and presented new heroes and a morale that rationalized the shift from state to market. It is not at all surprising that Friedman received the Nobel Prize in Economics in 1976, only two years after Friedrich Hayek. Like Adam Smith and Keynes, it was not because they were right, but because the time was ripe.

It was the right time, and it was not just a matter of mirroring the changes that went on in the real world. The narrative was performative. The dramatic institutional changes that took place after the 1970s happened because of a new, coherent narrative that made sense of the world in a new way, assigned new causality and appointed new heroes and villains, and presented a new morale. This narrative legitimized deregulation, privatization, and a new culture of personal enrichment not least in the financial industry and new research by

46. For an interesting view of the role of academia in this shift from belief in the state to belief in the market, see Moss, "Reversing the Null."

47. Friedman and Schwartz, A Monetary History of the United States, 18671960; Friedman, "A Friedman Doctrine - the Social Responsibility of Business Is to Increase Its Profits"; Jensen and Meckling, "Theory of the Firm”; Stigler, "The Theory of Economic Regulation," and Jensen Murphy, "CEO Incentives." 
University of Chicago professor Eugene Fama further contributed to and institutionalized belief in efficient financial markets. ${ }^{48}$

Despite this belief, among finance professors anyway, in efficient financial markets, finance ceased to be seen as a servant to the economy. On the contrary, as if he were rebuking Alfred Horwitz' statement from 1917, Larry Summers stated in 1997, "financial markets don't just oil the wheels of economic growth-they are the wheels." 49 There's an interesting discrepancy here, since it is hard to see how efficient markets, understood as "a market in which prices always 'fully reflect' available information," can at the same time be the "wheels" or the driver of the economy as suggested by Summers. ${ }^{50}$

More generally, signs of the optimism and belief in markets and finance were everywhere. It was New Era thinking, whether in the shape of stories about "the end of inflation," "Dow Jones 36,000," "the New Economy," or "the Great Moderation" or just plain and simple overoptimistic belief in models and financial institutions' capabilities. For instance, in September 2006, then CEO of Danske Bank, Peter Straarup, gave a talk on the lessons of the financial crisis of the early 1990s. He argued that

The rating of the loan portfolios quality that most financial institutions use today, means that we get much earlier warnings about debtors' inability to service their debts. In addition, I believe that the institutions have become much better at initiating action programs for loans that look weak. In addition, stress tests have improved significantly through the years.

Later in the same talk, Straarup added that the last 20 years' of disintermediation

have fundamentally changed the role of banks. We are becoming still better to profit from mediating risk rather than just taking risks. The explanation is advancement in both technology and financial theory. There are a lot of signs that financial derivatives have actually contributed to financial stability. ${ }^{51}$

Danish public discourse said about Peter Straarup that he was just like his predecessor Cold Tage, but without his human warmth. Of course,

48. Fama, "Efficient Capital Markets." See also Mackenzie, An Engine, Not a Camera: How Financial Models Shape Markets.

49. Davis, "Politics and Financial Markets," 44. See also Davis, Managed by the Markets.

50. For the definition of efficient markets, see Fama, "Efficient Capital Markets:

A Review of Theory and Empirical Work," 383.

51. Straarup, "Finansielle kriser." Translation by the author. 
this was not at all based on any actual knowledge about Straarup, but rather a part of the narrative about him as a CEO who was rational, calculating, and capable-in other words, good for business.

Another example of New Era thinking is then Federal Reserve Board governor, Ben Bernanke, who in discussing the Great Moderation assumed without a doubt that the Great Moderation was a fact, not just a story. Among the many factors that contributed to this was, according to Bernanke, "the increased depth and sophistication of financial markets, deregulation in many industries, the shift away from manufacturing toward services, and increased openness to trade and international capital flows ...” Bernanke also congratulated the Federal Reserve Bank of having fought inflation successfully and thereby contributed to the Great Moderation. ${ }^{52}$

As we all know now, there was no Great Moderation, no substantially improved running of financial institutions, and financial derivatives did not contribute to financial stability. It all blew up, and I would argue that the collapse happened because of the excessive role of finance and of financial thinking and motives in society at large, brought on by a new narrative. New Era narratives created the foundation for believing that property prices and share prices would rise forever. The lessons from the Great Depression and the many financial crises from 1980 to 2000s including the dot.com bubble were all forgotten. Over-optimism and overconfidence driven by New Era narratives focused on the supreme risk-handling role of finance ruled the day. ${ }^{53}$

For instance, here is what Joseph Cassano of the AIG Financial Products in London had to say in August 2007 about the Credit Default Swaps issued by his group:

It is hard for us, without being flippant, to even see a scenario within any kind of realm of reason that would see us losing one dollar in any of those transactions. ${ }^{54}$

AIG Financial Products was the financial arm of AIG, an insurance company with more than 100,000 employees. Nevertheless, the 300 employees of the AIG FP generated the losses that forced the United States Government to bail out the main corporation in September 2008 at the cost of about 170 billion dollars.

Now, it is important to emphasize that none of these people were stupid or evil, I am sure. Together with millions of other people, they were

52. Bernanke, “The Great Moderation.” Accessed July 22, 2014.

53. The concepts of "over-optimism" and "overconfidence" are part of the vocabulary of behavioral finance. See, for instance, Lai, "The Norwegian Banking Crisis," and de Bondt, "Bubble Psychology."

54. Morgenson, "Behind Insurer’s Crisis.' 
trapped in and reproducing a narrative that made sense of the world and the role of finance in a very specific way. This narrative was a subnarrative of the grand narrative of neo-liberalism and Modern Finance, and - as so many times before-it led to excessive optimism, overconfidence and, by implication, risk-taking. This is the stuff bubbles are made of. The overall narrative could, I suppose be summed up in Financial Times's well known add, "We live in Financial Times." Indeed.

In Framing finance, Alex Preda argues that

If it is true that we live now in an economic age, and that the new master narrative has abandoned the social for the economic, then finance is the master of this master narrative. ${ }^{55}$

The result of this shift, of course, is heavily debated. What cannot be debated is the fact that since the neo-liberal grand narrative came to dominate, financial instability has increased dramatically.

In terms of finance as a master narrative, this development is not at all surprising, given the enormous influence Modern Finance theory has exerted on academics and practitioners. The efficient market hypothesis and the increasing reliance on complex mathematical models contributed to the idea that the state was just an unnecessary or even harmful intervenor in a perfectly balanced economic and financial system. In particular on Wall Street in the big investment banks, the shareholder value narrative influenced not only the internal culture of these organizations (with detrimental consequences) but also the worldview of analysts and managers in companies. ${ }^{56}$

A number of scholars have coined the term financialization to describe this development. ${ }^{57}$ Of course, concepts are not neutral either; they too contribute to both describing and shaping the world, and they do not have a fixed meaning. For the purpose of this talk, the definition given by Epstein makes good sense:

Financialization means the increasing role of financial motives, financial markets, financial actors and financial institutions in the operation of the domestic and international economies. ${ }^{58}$

In some way, Robert Wade has also put it nicely, that financialization is about "finance financing finance." ${ }^{59}$ More generally, financialization

55. Preda, Framing Finance, 1. Preda partly builds on Judt, "The Wrecking Ball of Innovation."

56. Ho, Liquidated, and Ho, "Disciplining Investment Bankers."

57. See, in particular, Dore, "Financialization of the Global Economy"; Epstein, Financialization and the World Economy; Krippner, Capitalizing on Crisis, and Mukunda, "The Price of Wall Street's Power."

58. Epstein, "Introduction: Financialization and the World Economy," 3.

59. Wade, "From Global Imbalances to Global Reorganisations," 548. 
is characterized by increasing credit, debt, leverage, and short-termism promoted by investment banks, hedge funds, and analysts among others-a result of a cultural shift in the way observers make sense of finance, the company and executive performance. Overall, financialization is characterized by a shift in the perception of the people from being citizens to consumers and investors. ${ }^{60}$

Financialization, or globalized finance, has been examined in quantitative terms by Thomas Philippon and Ariell Reshef. While they are very careful not to say too much, they still conclude,

the rise of the financial sector is sometimes defended by arguing that a more developed financial sector encourages economic growth. ... But it is quite difficult to make a clear-cut case that at the margin reached in high-income economies, the expanding financial sector increases the rate of economic growth. The long-run patterns of the rise of the financial sector since the nineteenth century ... do not have any obvious correlation with trends in growth rates within countries. ${ }^{61}$

The authors continue that it is still an open question whether "the social benefits outweigh the costs of the growth of finance", and somewhat amusingly they continue that "it is difficult to believe that the growth of finance has not come with some benefits ...." They then conclude, "researchers are still in the process of building a model that adequately explains the rise of the financial sector." 62

Why am I not reassured? If we want to understand the rise of finance and the disproportionate size and role of the industry in the economy and society more generally, more models are hardly the way forward. We must focus on how narratives have represented and promoted unrestrained financial markets and institutions as imperative for our continued well-being. Interestingly, there are two peaks in the data that Philippon and Rasheff present for the United States: The share of finance relative to GDP and finance's share of wages peak around 1930 and 2008, and the same goes for total debt in the United States. ${ }^{63}$

Is it coincidental that these peaks correlate with the periods of finance capitalism and financialization, and extreme financial instability? Hardly. These are the financial times in which we are

60. Dore, "Financialization of the Global Economy."

61. Philippon and Reshef, "An International Look at the Growth of Modern Finance,” 92. See also Philippon, "Finance Vs. Wal-Mart.”

62. Philippon and Reshef, "An International Look at the Growth of Modern Finance."

63. Ibid; 92. See also Philippon, "Finance Vs. Wal-Mart.” For debt relative to GDP, see "Deleveraging. A Fate Worse Than Debt." See also Mukunda, "The Price of Wall Street's Power." 
living with too much finance for our own good. Even The Economist has argued

the central question that the finance industry needs to answer is this: why has its increased importance been associated with slower economic growth in the developed world and a greater number of asset bubbles? ${ }^{64}$

As already emphasized, financialization is not given by God or by nature, it is a cultural process where we come to increasingly see the world in financial terms. This financialization process is the result of narratives that have led not only to financial instability and increasing inequality of our societies since the 1970s. Concurrently with financialization and no doubt related, the number of large business scandals involving a significant degree of financial thinking has increased.

The first signs of financial fragility came with the Herstatt Bank failure in Germany in 1974 and the secondary banking crisis in the United Kingdom in 1973-1975. In the 1980s, banking problems intensified with the Continental Illinois Bank's failure in 1984 and the Savings \& Loan crisis in the second half of the 1980s. Then followed, the Scandinavian financial crisis in the early 1990s, the East Asian financial crisis in 1997-1998, the Dot.com crash in 2001, and the Great Financial Crisis of 2007-2008. In addition and related we had a number of notable business scandals such as the failure of Metallgesellschaft, Barings Bank, Tyco, Enron, Parmalat, and Royal Ahold. ${ }^{65}$

Coupled with the failure of Bear Stearns, Lehman Brothers and a considerable number of other large financial institutions around the world, it is hard to see these companies as just individual bad apples. Most of the failures and scandals were related to an overwhelming focus on financial thinking and the use of new financial instruments. And let us not forget that it is getting more and more difficult to read Financial Times without news of yet another big multinational bank being fined for problematic or outright illegal practices. It is not bad apples. It is cultural and it is the result of financialization.

Closely connected to this financial thinking were the rise of shareholder value capitalism and the spread of a negative narrative about managerial or stakeholder capitalism. The new financial capitalists such as Kohlberg Kravis Roberts were represented as "The masters of the buyout game" on the front cover of Fortune, and as the saviors of

64. "Buttonwood. Counting the Cost of Finance."

65. See Hamilton and Micklethwait, Greed and Corporate Failure; Drummond, "Living in a Fool's Paradise." 
an ineffective capitalism. Unsurprisingly, this is also how the richest legitimized their fortunes. ${ }^{66}$ Even in Denmark, "hostile takeovers" became accepted and Per Villum Hansen, who had been persona non grata in Danish business since the failure of Hafnia in 1992, felt vindicated in 2008: "Many of the things I was scolded for in the 1980s happens all the time in Danish business today; for instance private equity funds and hostile takeovers. Back then, you could hardly mention the word without people panicking." ${ }_{67}$ And Danske Bank that ever since the crisis in the 1920s had nursed a reputation for conservative and risk-averse banking, came in trouble because of over-leveraging and overexpansion not least into the Irish market. The bank thus lived up to Jack Revell's claim that free competition in banking leads to a kind of Gresham's law where bad banking drives out good banking. ${ }^{68}$

The process of financialization was also noticed by Hollywood, of course. Movies such as Wall Street, Pretty Woman, Other People's Money, and Barbarians at the Gate from around 1990 all dealt with the new financial capitalists. ${ }^{69}$ Obviously, these movies were cultural reflections of the turn to finance that had been going on for a decade when they were released. However, it is a sound hypothesis that they were also performative in the sense that they shaped the public's perception of the role of finance in society. Needless to say, none of these movies were particularly positive toward the financial industry. However, the case has been made, that Wall Street was received very positively on-Wall Street, where Gordon Gecko seems to have been regarded as the hero rather than the villain. The impact of Wall Street the movie on Wall Street thus confirms Karen Ho's analysis of investment bankers, and illustrates how the film has both reflected and contributed to the shaping of deeply problematic organizational cultures in investment banks. ${ }^{70}$

It seems to me that there is more than enough evidence to warrant the use of the financialization concept. The concept seems to be particularly appropriate if we want to understand the most recent 20-25 years of changes in the institutional framework and organizational culture and behavior in the financial sector. In addition,

66. Baker and Smith, The New Financial Capitalists; Uchitelle, "The Richest of the Rich, Proud of a New Gilded Age."

67. Johnsen, "Per Villum: jeg blev presset ud af Danmark" (http://www.business.dk/navne/per-villum-jeg-blev-presset-ud-af-danmark). Accessed July 23, 2014. Author's translation.

68. Revell, "The Complementary Nature of Competition and Regulation in the Financial Sector."

69. Stone, "Wall Street"; Marshall, "Pretty Woman”; Jewison, "Other People’s Money"; and Jordan, "Barbarians at the Gate."

70. Guerrera, "How 'Wall Street' Changed Wall Street”; Ho, Liquidated; and Ho, "Disciplining Investment Bankers." 
there are similarities with Hilferding's concept of finance capitalism, which suggests that the comparison between the period from 1870 to 1931 and from the 1970s to today is a fruitful one. At the same time, there are of course, differences. For instance, as Epstein's definition suggests and Ronald Dore elaborates upon, finance has become much more prevalent in everyday life than was the case during the era of finance capitalism and, of course, in the era of the social state. ${ }^{71}$

Financialization is also a state of mind, a cultural blueprint where everything is evaluated according to pecuniary value. We are no longer citizens in a nation but instead we are consumers and investors in the competition state. We must take care of our own savings, investments, and pension funds, if we are lucky enough to have any. Microeconomics and the idea of the so-called consumer surplus is part of the neo-liberal narrative, but however big the consumer surplus is, it is hardly a match for the financial instability and rent-seeking activities of the financial sector.

In other words, until 2008, the new neo-liberal financial narrative had presented an anything goes story legitimizing all kinds of financial practices. After all, financial markets are efficient, are they not? And to make matters worse, the fall of the Berlin Wall and the Soviet Union-in itself an event to be celebrated-eliminated the alternative narrative that had at least constrained the degree to which labor could be subordinated to capital. It was not the end of history, but it was the victory of unrestrained finance. The effects of this development were many.

\section{Consequences of the New Finance Narrative}

First and foremost, the consequence of financialization that resulted from the neo-liberal narrative has been financial instability. Hyman Minsky argued that there was a built-in tendency for what he called the "Wall Street paradigm" to increase debt, leverage, and thus financial instability over time. To Minsky, this was primarily an economic process helped on its way by the short memory of bankers and the resulting euphoric economy. ${ }^{72}$ However, I would argue, once again, that economy and culture cannot be meaningfully separated. The euphoric economy and the Wall Street economy results from the processes presented previously.

These processes are to a large degree cultural, and as a result, Wall Street and the financial industry more generally has shaped the world

71. See also Reich, Supercapitalism; Drummond, "Living in a Fool's Paradise”; Dore, "Financialization of the Global Economy"; and Glyn, Capitalism Unleashed.

72. Minsky, "A Theory of Systemic Fragility,” 143, 146. 
in its own image by spreading the narrative of efficient markets, meritocracy and shareholder value. In the United States and probably elsewhere, this process has made it possible for financial institutions and what Thomas Piketty calls "super-managers" to reap "compensation packages" beyond what a theoretical model of "perfect markets" could ever justify. ${ }^{73}$

In the financial sector, profits have been privatized, while the costs of the financial crisis have been socialized. In addition, several scholars and observers argue that the financial industry's "social value" is smaller than its profits and that the sector is, therefore, rent seeking. For instance, the Financial Times argued in an editorial in 2010 that

So long as banking generates profits far above its social productivity, that excess will find its way to bankers' pockets. No regulation of pay can solve this deep difficulty on its own; what is needed is to change the reality that creates economic rent in the first place. ${ }^{74}$

Bruce Kogut, too, has argued that finance has schooled rent seekers, and so have Joseph Stiglitz, Robert Shiller, and others. ${ }^{75}$ At least part of what made the financial sector's rent-seeking activities successful was the narrative that enabled vested interests to perform a cultural capture, where decision-makers, analysts, and many others came to see the world in the same way as the financial industry. The result has been that policymakers and regulators have not lived up to the public's expectations that finance would be properly regulated. ${ }^{76}$

The financial crisis was the result, and banks had to be bailed out by the tax-payers, who have experienced a rise in unemployment and a continuing deterioration of their living standards in many countries. Not least members of the middle class have come under considerable pressure, and probably felt like they had the most to lose. ${ }^{77}$ Part of this tendency, as Thomas Piketty has shown, is the result of a long-term change in the income shares of the different income deciles in society. Another part can best be explained by the politics of austerity, which, like during the Great Depression, has increased

73. Glyn, Capitalism Unleashed, 50-2; Piketty, Capital in the 21st Century, $330-5$.

74. "The Moving Target of Bankers' Bonuses."

75. Kogut and Patrick, "The Quantitative Revolution and the Crisis," 22; Stiglitz, The Price of Inequality, 35-64; and Shiller, "The Best, Brightest, and Least Productive?"

76. Kwak, "Cultural Capture and the Financial Crisis." For a corresponding idea-cognitive regulatory capture-see Buiter, "Lessons from the North-Atlantic Crisis.” See also Johnson, "The Quiet Coup.”

77. Peck, "Can the Middle Class Be Saved?"; James, The Creation and Destruction of Value, 30-1. 
unemployment through so-called "internal devaluations"-or outright deflationary policies, which present a sense of déjà vu going back to the Great Depression. In his eminent book on austerity, Mark Blyth does not hesitate to call this policy class politics. ${ }^{78}$

The result has been that the division of GDP between labor and capital has changed to the advantage of capital over the last three decades, and that labor more generally has lost power, as Jeffrey Sklansky makes clear. Not surprisingly, the upper decile and the uppermost centile have experienced a rise in income, while the middle class and the lowest five deciles' share of income have declined. In other words, both income and wealth inequality have increased just like it did during finance capitalism. ${ }^{79}$ Scholars such as Greg Mankiw have defended this development and the riches of the "one percent" and argued that inequality will increase economic growth and therefore the "pie." However, it also matters how the pie is sliced, and other scholars have argued that inequality increases financial and social instability and harms social mobility. From that perspective, the last 30 year's increase in income and wealth inequality seems like a particularly bad idea. In addition, Piketty, for instance, has convincingly contested the neo-classical narrative that compensation is based on the marginal productivity of "super-managers." 80

Since the neo-liberal narrative came to dominate from the 1980s, and in particular from the 1990s when the social state narrative became seriously contested by globalization and deregulation, Western societies have been in the process of substituting the competition state for the social state. ${ }^{81}$ In addition, the fall of the Berlin wall and the breakdown of the Soviet Union (I am not referring here to the Soviet Union as a place people would want to live, but as an alternative narrative) increased the relative power of the neo-liberal narrative. It is worth remembering that Paul Samuelson in the eighth edition of his famous economic textbook from 1970 predicted that the Soviet Union might overtake US GDP sometime between 1990 and 2000. And in the thirteenth edition from 1989 just before the fall of the Berlin wall, he argued that the Soviet system had shown that it could "function and even thrive." 82

78. Blyth, Austerity. The History of a Dangerous Idea.

79. Piketty, Capital in the 21st Century; Piketty and Saez, "Inequality in the Long Run"; "Labor Pains"; Sklansky, "Labor, Money, and the Financial Turn in the History of Capitalism."

80. Mankiw, "Defending the One Per Cent." For scholars who argue that inequality is a problem for stability, see Rajan, Fault Lines; Galbraith, Inequality and Instability; Piketty, Capital in the 21st Century, and Stiglitz, The Price of Inequality.

81. Glyn, Capitalism Unleashed, 15-21.

82. Piketty, Capital in the 21st Century, 137; and http://drmatthewashton. com/2012/07/10/political-predictions-they-got-wrong-no31-paul-samuelsons-economics/. Accessed July 23, 2014. 
However, what I am getting at here is that, until the breakdown of socialism in 1989 and 1990, employers needed to consider the risk of labor conflict. While the rise of the neo-liberal narrative and the related movement toward globalization and financialization was the most important single "factor" to put pressure on labor and the middle classes, the disappearance of the "socialism" counter-narrative contributed to this increasing pressure. The result has been a significant decline in the role of unions as proponents of the social state narrative, as I have also shown in my book on the Financial Services Union Denmark. ${ }^{83}$

Thus, while the period of finance capitalism was marked by an increase in the influence of labor and the alternative narrative represented by social democratic parties and unions, the opposite has been the case during financialization. It is tempting to see the fall of finance capitalism as linked to the rise of labor and its narrative, and the rise of financialization as linked to the fall of labor and its narrative. The result has been that the counter-narratives of, say, "los indignados" in Spain or "Occupy Wall Street" in the United States are too weak and without a strong institutional and organizational basis (while the tea-party movement has been more successful). In the meantime, the social and financial instability linked to finance capitalism has reappeared with financialization, and both times, globalization was a companion that contributed to the rise of finance, instability, and the competition states' race to the bottom. The antiglobalization movement's inability to construct an attractive and convincing counter-narrative made it impossible to plausibly compete with the globalization narrative. However, as Harold James has argued, globalization is hardly the "end of history" either. ${ }^{84}$

It is clear that Western societies are trying very hard at the moment to make sense of future development lines. Like every time, societies go through crises there has been a loss of meaning and a semantic struggle is going on between competing narratives that rationalize and legitimize different perspectives. With respect to the financial crisis, this sense-making process has resulted in a number of commissions appointed to examine what caused the crisis. ${ }^{85}$

83. Hansen and Jensen, Vi kan når vi skal.

84. James, The End of Globalization; James, The Creation and Destruction of Value. See also, Reich, Supercapitalism, and Glyn, Capitalism Unleashed.

85. For the United States, see Financial Crisis Inquiry Commission, "The Financial Crisis Inquiry Report.” For Denmark, see Rangvid, "Den finansielle krise i Danmark." For an English summary of the Danish commission report, see http:// www.evm.dk/publikationer/2013/ /media/oem/pdf/2013/2013-publikationer/1809-13-rapport-fra-udvalget-om-finanskrisens-aarsager/conclusions-and-recommendations-170913.ashx. Accessed July 23, 2014. 
Unsurprisingly, there is no agreement as to what caused the financial crisis. There are different narratives that fit very well with the grand narratives and the Minsky-Kindleberger vs. the monetarist/ Austrian stories already laid out: The crisis was caused by the financial system or the crisis was caused by state and central bank intervention in the economy. ${ }^{86}$ As usual, Hollywood has contributed with its own narratives such as The company men, Too big to fail, Margin call, and Arbitrage. ${ }^{87}$

Of course, the really interesting question is whether the financial crisis and the Great Recession is an event of such magnitude that a new more state-friendly narrative (or some other counter-narrative) will eventually come to dominate when the sense-making process settles. This is what happened after the Great Depression and two World Wars, and in the 1970s, after the oil shock and the stagflation crisis when the statefriendly narrative was reversed. For a while in late 2008-2009, it looked like such a new narrative might be under way, but the European debt crisis effectively made a state-friendly narrative impossible, despite the argument made by Mark Blyth that—apart from Greece—-the public deficits were mostly a result of taxpayer bailouts of the financial system. ${ }^{88}$

One should probably not underestimate the anger and despair of the people in the United States, Greece, Spain, and elsewhere. It may take different expressions in the shape of social unrest, democratic distrust, and right wing extremism-not that different from the 1930s. If Thomas Piketty is right that income and wealth inequality will continue to rise, while the middle and lower classes' conditions deteriorate, some intervention will be needed in order to stop social and financial instability from getting any worse. Historically, financial, economic, and social crises like the current one have been eased when a new narrative arose that could make sense of anomalies in the dominant narrative, thus legitimizing and paving the way for change. How, why, and when that happens is a matter of power exercised through narratives. Considering that the two most serious financial crises and economic depressions in the twentieth and twenty-first centuries happened when the power of the financial sector was at its peak gives food for thought.

There are signs of counter-narratives, for instance with regard to the dominance of the shareholder value narrative, which is being challenged by a number of scholars and practitioners. ${ }^{89}$ Also the many

86. See also, Hansen, "Making Sense of Financial Crisis and Scandal."

87. Wells, "The Company Men”; Hanson, "Too Big to Fail”; Chandor, "Margin Call”; and Jarecki, "Arbitrage." Of course, there is also the book on which the film "Too big to fail" is based: Sorkin, Too Big to Fail.

88. Blyth, Austerity. The History of a Dangerous Idea, 51-93.

89. See for instance, Stout, The Shareholder Value Myth; Fox and Lorsch, "What Good Are Shareholders?"; Nocera, "Down with Shareholder Value"; and Mukunda, "The Price of Wall Street’s Power." 
important books on inequality may have the potential to offer a powerful counter-narrative, but this remains to be seen..$^{90}$ Basically this is a question of power. Since the 1980s, the financial sector and more generally the business sector's power has increased dramatically, and while this power is economic and political, its foundation is cultural. It is based on a shared worldview between politicians and financiers resulting from the narrative that finance constitutes the wheels. And that is a result of cultural capture. Interestingly, according to Jeffrey Sklansky, recent historians of capitalism have contributed to this process of making finance into the wheels of capitalism, by projecting the role of finance in the era of financialization back in time. ${ }^{91}$ If so, I am probably guilty of doing the same thing here, but it is also a sign then, of how strong and influential the finance narrative has been over the last few decades. Even business historians' worldview has changed.

\section{The End}

In this talk, I have argued that finance can be analyzed historically with a cultural approach that focuses on the industry's changing power and societal influence in a dynamic context. By cultural approach, I mean a process of sense making through performative narratives that legitimize and co-construct social reality by assigning meaning and causality to events and phenomena.

I have argued that the role of finance has changed dramatically a number of times between 1850 and 2014. During this period, finance has both been a servant and a master, and it has mattered a great deal what role it played. During the early part of the twentieth century, finance came to play the role of master-what Hilferding called finance capitalism. The interwar period effectively ended that situation when a new narrative became dominant; that of the social state. In the era of the social state from around 1945 to the 1970s, finance came to play the role of servant, and the result was more stable societies in financial and social terms.

From the 1970s, however, the social state narrative could no longer adequately make sense of and explain the problems of the time. The result was the rise of a new neo-liberal narrative that paved the way for the current era of financialization.

While finance is indispensable in modern capitalist societies, I would argue that when it becomes a master it leads to financial and

90. See also my review of Piketty's Capital in the twenty-first century in Hansen, "Review Essay: Thomas Piketty, Capital in the Twenty-First Century."

91. Sklansky, "Labor, Money, and the Financial Turn in the History of Capitalism,” 34-5. 
social instability. This is so because finance as a master becomes too powerful, which leaves room for rent seeking, regulatory capture, and out-of-control financial innovation. It also seems that there is a relation between globalization and too much finance.

Narratives are important instruments in this development because they co-construct and legitimize regimes by framing the way we see the world. Narratives are not author-less discourses, but represent specific, powerful interests and make cultural capture by the financial sector of the political system possible.

As historians we analyze and construct narratives, and like other cultural texts such as books, theories, films etc., our narratives also play an important role in framing our topics. In the introduction, I argued that the social sciences are not objective disciplines, and therefore our traditional adherence to archives and source criticism as the backbone of historical methods is problematic. The idea of historical methods as closely related to primary sources located in historical archives often leads us to "fly too low" over the sources. Business historians must increase the altitude and ask big questions that matter to contemporary society. Questioning power is an important part of this.

This leads me to one final point and one final question. The final point is this: When trying to understand finance we should not only follow the money, we should also follow the story. The final question is this: If there is no neutral observation point for historians, and if historians' narratives are performative and part of the ongoing conversation, does this mean that business history has a social responsibility?

\section{Bibliography of Works Cited}

\section{Books}

Abolafia, Mitchel Y. Making Markets. Opportunity and Restraint on Wall Street. Cambridge, MA: Harvard University Press, 1996.

Akerlof, George, and Robert J. Shiller. Animal Spirits: How Human Psychology Drives the Economy, and Why It Matters for Global Capitalism. Princeton, NJ: Princeton University Press, 2009.

Anderson, Benedict. Imagined Communities. Reflections of the Origin and Spread of Nationalism. Rev ed. New York: Verso, 1991.

Baker, George P., and George D. Smith. The New Financial Capitalists. Kohlberg, Kravis Roberts and the Creation of Corporate Value. New York: Cambridge University Press, 1998.

Birck, Laurits V. Under højkapitalismen. København: Martins Forlag, 1935. . Verdenskrisen og Danmark. København: Gyldendalske Boghandel, 1922. 
Blyth, Mark. Austerity. The History of a Dangerous Idea. Oxford, NY: Oxford University Press, 2013.

Brandeis, Louis D. Other People's Money: And How the Bankers Use It. 2009 ed. Mansfield Centre, CT: Martino Publishing, 1914.

Bucheli, Marcelo, and R. Daniel Wadhwani, eds. Organizations in Time. History, Theory, Methods. New York: Oxford University Press, 2014.

Cetina, Karin K., and Alex Preda. The Oxford Handbook of the Sociology of Finance. Oxford: Oxford University Press, 2012.

Chernow, Ron. The Death of the Banker. The Decline and Fall of the Great Financial Dynasties and the Triumph of the Small Investor. 1st ed. New York: Random House, 1997.

Davis, Gerald F. Managed by the Markets. How Finance Reshaped America. Oxford: Oxford University Press, 2009.

Eichengreen, Barry. The European Economy since 1945: Coordinated Capitalism and Beyond. Princeton, NJ: Princeton University Press, 2007.

—. Golden Fetters. The Gold Standard and the Great Depression, 19191939. Oxford: Oxford University Press, 1992.

Epstein, Gerald A., ed. Financialization and the World Economy. Cheltenham, UK: Edward Elgar, 2005.

Fox, Justin. The Myth of the Rational Market: A History of Risk, Reward, and Delusion on Wall Street. New York: Harper, 2009.

Friedman, Milton, and Anna J. Schwartz. A Monetary History of the United States, 1867-1960. Princeton, 1963.

Galbraith, James K. Inequality and Instability. A Study of the World Economy Just before the Great Crisis. New York: Oxford University Press, 2012.

Gerschenkron, Alexander. Economic Backwardness in Historical Perspective. Cambridge, MA: Belknap Press, 1962.

Glyn, Andrew. Capitalism Unleashed. Finance, Globalization, and Welfare. Oxford: Oxford University Press, 2006.

Grossman, Richard S. Unsettled Account. The Evolution of Banking in the Industrialized World since 1800. Princeton, NJ: Princeton University Press, 2010.

Hamilton, Stewart, and Alicia Micklethwait. Greed and Corporate Failure. The Lessons from Recent Disasters. New York: Palgrave MacMillan, 2006.

Hansen, Per H. Da sparekasserne mistede deres uskyld. En historie om sparekasser og samfund i opbrud. Odense, Denmark: Syddansk Universitetsforlag, 2001.

—. På glidebanen til den bitre ende. Dansk bankvæsen i krise, 1920-1933. Odense, Denmark: Odense Universitetsforlag, 1996.

Hansen, Per H., and Kristoffer Jensen. Vi kan når vi skal. Finansforbundets historie. Odense, Denmark: University Press of Southern Denmark, 2013.

Hansen, Per H., and Søren Mørch. Den Danske Bank. 1st ed. Viby, Denmark: Forlaget Centrum, 1997.

Hilferding, Rudolf. Finance Capital. A Study of the Latest Phase of Capitalist Development. London: Routledge \& Kegan Paul, 1981.

Ho, Karen. Liquidated. An Ethnography of Wall Street. Durham, NC: Duke University Press, 2009. 
Horwitz, Alfred. Minut-Millionærer. Økonomiske Tidsbilleder fra Krigs- og Efterkrigsaarene. København: Levin \& Munksgaard, 1923.

James, Harold. The Creation and Destruction of Value. The Globalization Cycle. Cambridge, MA: Harvard University Press, 2009.

- The End of Globalization. Lessons from the Great Depression. Cambridge, MA: Harvard University Press, 2001.

Jordanova, Ludmilla. History in Practice. London: Arnold, 2000.

Keynes, John M. The General Theory of Employment, Interest and Money. London: Macmillan \& Co., 1936.

Kindleberger, Charles P., and Robert Z. Aliber. Manias, Panics and Crashes. A History of Financial Crises. 6th ed. New York: Palgrave MacMillan, 2011.

Krippner, Greta R. Capitalizing on Crisis. The Political Origins of the Rise of Finance. Cambridge, MA: Harvard University Press, 2011.

Mackenzie, Donald. An Engine, Not a Camera: How Financial Models Shape Markets. Cambridge, MA: MIT Press, 2008.

Partnoy, Frank. The Match King: Ivar Kreuger, the Financial Genius Behind a Century of Wall Street Scandals. London: Profile Books 2009.

Piketty, Thomas. Capital in the 21st Century. Cambridge, MA: The Belknap Press of Harvard University Press, 2014.

Preda, Alex. Framing Finance. The Boundaries of Markets and Modern Capitalism. Chicago: University of Chicago Press, 2009.

Rajan, Raghuram. Fault Lines: How Hidden Fractures Still Threaten the World Economy. Princeton, NJ: Princeton University Press, 2010.

Reich, Robert. Supercapitalism. The Transformation of Business, Democracy, and Everyday Life. New York: Alfred A. Knopf, 2007.

Schumpeter, Joseph A. The Theory of Economic Development. An Inquiry into Profits, Capital, Credit, Interest, and the Business Cycle. Cambridge, MA: Harvard University Press. 1934.

Sorkin, Andrew R. Too Big to Fail: The Inside Story of How Wall Street and Washington Fought to Save the Financial system--and Themselves. New York: Penguin, 2009.

Stiglitz, Joseph E. The Price of Inequality. New York: Penguin Books, 2012.

Stout, Lynn. The Shareholder Value Myth. How Putting Shareholders First Harms Investors, Corporations, and the Public. San Francisco: BerrettKoehler Publishers, 2012.

Tett, Gillian. Fool's Gold: How the Bold Dream of a Small Tribe at J.P. Morgan Was Corrupted by Wall Street Greed and Unleashed a Catastrophe. New York: Free Press, 2009.

Zaloom, Caitlin. Out of the Pits. Traders and Technology from Chicago to London. Chicago: Chicago University Press, 2006.

\section{Articles, Chapters, and Reports}

Barton, Laura. "On the Money." The Guardian October 31, 2008.

Bernanke, Ben S. "The Great Moderation." In Remarks by Governor Ben S. Bernanke. At the meetings of the Eastern Economic Association, Washington, DC, February 20, 2004. The Federal Reserve Board, 2004. http://www.federalreserve.gov/Boarddocs/Speeches/2004/20040220/ 
Buiter, Willem H. "Lessons from the North-Atlantic Crisis." London School of Economics, 2008. http://newyorkfed.org/research/conference/2008/rmm/ buiter.pdf. Accessed August 22, 2014.

"Counting the Cost of Finance." The Economist June 21, 2014, 66.

Davis, Gerald F. "Politics and Financial Markets." In The Oxford Handbook of the Sociology of Finance, edited by K. K. Cetina and A. Preda, 33-51. Oxford: Oxford University Press, 2012.

de Bondt, Verner. "Bubble Psychology." In Asset Price Bubbles. The Implications for Monetary, Regulatory, and International Policies, edited by W. C. Hunter, G. G. Kaufman and M. Pomerleano, 205-16. Cambridge, MA: MIT Press, 2003.

"Deleveraging. A Fate Worse Than Debt." The Economist September 25, 2008.

Dore, Ronald. "Financialization of the Global Economy." Industrial and Corporate Change 17, no. 6 (2008): 1097-112.

Drummond, Helga. "Living in a Fool's Paradise: The Collapse of Barings' Bank.” Management Decision 40, no. 3 (2002): 232-38.

Eichengreen, Barry, and Peter Temin. "Fetters of Gold and Paper." Oxford Review of Economic Policy 26, no. 3 (2010): 370-84.

Eichengreen, Barry, and Richard Portes. "The Anatomy of Financial Crises." In Threats to International Financial Stability, edited by Richard Portes \& A. K. Swoboda, 10-58. Cambridge: Cambridge University Press, 1987.

Eichengreen, Barry. "Mainsprings of Economic Recovery in Post-War Europe." In Europe's Post-War Recovery, edited by B. Eichengreen, 3-35. Cambridge: Cambridge University Press, 1995.

Epstein, Gerald A. "Introduction: Financialization and the World Economy." In Financialization and the World Economy, edited by G. A. Epstein, 3-16. Cheltenham, UK: Edward Elgar, 2005.

Fama, Eugene. "Efficient Capital Markets: A Review of Theory and Empirical Work." Journal of Finance 25, no. 2 (1970): 383-417.

Financial Crisis Inquiry Commission."The Financial Crisis Inquiry Report, Authorized Edition: Final Report of the National Commission on the Causes of the Financial and Economic Crisis in the United States." New York, NY: PublicAffairs, 2011.

Fisher, Irving. "The Debt-Deflation Theory of Great Depressions." Econometrica 1, no. 4 (1933): 337-57.

Foss, Alexander. "Danmark som Industriland." Tidsskrift for industri (1912): 33-50.

Fox, Justin, and Jay W. Lorsch. "What Good Are Shareholders?" Harvard Business Review July-August (2012): 48-57.

Friedman, Milton. "A Friedman Doctrine - the Social Responsibility of Business Is to Increase Its Profits.” New York Times Magazine September 13, 1970.

Guerrera, Francesco. "How 'Wall Street' Changed Wall Street." Financial Times September 24, 2010.

Hansen, Per H. "Bank Regulation in Denmark from 1880 to World War Two: Public Interests and Private Interests.” Business History 43, no. 1 (2001): 43-68. 
"Banker og økonomisk udvikling: Fyens Disconto Kasse som universalbank." In Folk og erhverv. Tilegnet Hans Chr. Johansen, edited by A. M. Møller, 181-200. Odense, Denmark: Odense Universitetsforlag, 1995.

_. "Business History: A Cultural and Narrative Approach." Business History Review 86, no. 4 (2012): 693-717.

- "The Danish Savings Banks Association and the Deregulation of the Savings Banks, 1965-1975." In Business and Society. Entrepreneurs, Politics and Networks in a Historical Perspective, edited by A-M. Kuijlaars, K. Prudon and J. Visser, 219-36. Rotterdam, 2000.

—_. "En højst ubehagelig situation.” Siden Saxo, no. 4 (1992): 44-49.

—. "From Growth to Crisis. The Danish Banking System from 1850 to the Interwar Years." Scandinavian Economic History Review, no. 3 (1991): 20-40.

_ _ . "Fyens Disconto Kasse, 1846-86. Indlån og udlån.” Erhvervshistorisk Årbog (1989): 98-137.

. "Fyens Disconto Kasse, 1846-1886. En undersøgelse af bankens kreditformidling, med særligt henblik på industriens finansiering." Unpublished Master's Thesis, Odense University, 1989.

—. "Making Sense of Financial Crisis and Scandal: A Danish Bank Failure in the Era of Finance Capitalism." Enterprise \& Society 13, no. 3 (2012): 672-706.

—. "Organizational Culture and Organizational Change: A Narrative Analysis of the Transformation of Savings Banks in Denmark, 1965-1990." Enterprise \& Society 8, no. 4 (2007): 920-53.

—. "Review Essay: Thomas Piketty, Capital in the Twenty-First Century." Business History Review 88, no. 3 (2014).

Hansen, Per H., and R. Daniel Wadhwani. "Can Business History and Anthropology Learn from Each Other?" Journal of Business Anthropology 3, no. 1 (2014): 51-9.

Ho, Karen. "Disciplining Investment Bankers, Disciplining the Economy: Wall Street's Institutional Culture of Crisis and the Downsizing of Corporate America." American Anthropologist 111, no. 2 (2009): 177-89.

Jensen, Michael C., and Kevin J. Murphy. “CEO Incentives - It's Not How Much You Pay, but How.” Harvard Business Review 68, no. 3 (1990): 138-49.

Jensen, Michael, and William H. Meckling. "Theory of the Firm: Managerial Behavior, Agency Costs and Ownership Structure.” Journal of Financial Economics 3, no. 4 (1976): 305-60.

Johnsen, Morten. "Per Villum: jeg blev presset ud af Danmark." Berlingske Tidende 5, (2008). http://www.business.dk/navne/ per-villum-jeg-blev-presset-ud-af-danmark

Johnson, Simon. "The Quiet Coup.” The Atlantic May 1, 2009.

Jones, Geoffry, and Ingrid Vargas. "Ivar Kreuger and the Swedish Match Empire.” Harvard Business School Case 804-078 (2004).

Judt, Tony. "The Wrecking Ball of Innovation." The New York Review of Books December 6, 2007.

Kogut, Bruce, and Hugh Patrick. "The Quantitative Revolution and the Crisis." The Sanford C. Bernstein \& Co. Center for Leadership and Ethics, 2009. 
Kwak, James. "Cultural Capture and the Financial Crisis." In Preventing Regulatory Capture: Special Interest Influence and How to Limit It, edited by D. Carpenter and D. A. Moss, 71-98. Cambridge, MA: Cambridge University Press, 2013.

"Labor Pains." The Economist November 2, 2013.

Lai, Linda. "The Norwegian Banking Crisis: Managerial Escalation of Decline and Crisis." Scandinavian Journal of Management 10, no. 4 (1994): 397-408.

Mankiw, Gregory N. "Defending the One Per Cent." Journal of Economic Perspectives 27, no. 3 (2013): 21-34.

McCracken, Grant. "Culture and Consumption: A Theoretical Account of the Structure and Movement of the Cultural Meaning of Consumer Goods." Journal of Consumer Research 13 no. 1 (1986): 71-84.

—. "When Cars Could Fly: Raymond Loewy, John Kenneth Galbraith, and the 1954 Buick." In Culture \& Consumption II. Markets, Meaning, and Brand Management, edited by Grant McCracken, 53-90. Bloomington, IN: Indiana University Press, 2005.

Minsky, Hyman. "A Theory of Systemic Fragility." In Financial Crises: Institutions and Markets in a Fragile Environment, edited by Edward I. Altman and Arnold W. Sametz, 138-52. New York: Wiley, 1977.

Mordhorst, Mads. "Arla and Danish National Identity: Business History as Cultural History.” Business History 56, no. 1 (2014): 116-33.

—. "From Counterfactual History to Counter-Narrative History." Management \& Organizational History 3, no. 1 (2008): 5-26.

Morgenson, Gretchen. "Behind Insurer's Crisis, Blind Eye to a Web of Risk." New York Times September 27, 2008.

Moss, David A. "Reversing the Null. Regulation, Deregulation, and the Power of Ideas." In Challenges to Business in the Twenty-First Century, edited by Gerald Rosenfeld, Jay W. Lorsch and Rakesh Khurana, 35-49. Cambridge, MA: American Academy of Arts and Sciences, 2010.

“The Moving Target of Bankers' Bonuses.” Financial Times October 7, 2010.

Mukunda, Gautam. "The Price of Wall Street's Power." Harvard Business Review June (2014): 70-8.

Nevers, Jeppe. "The Magic of Source-Criticism: Understanding a Key Concept in Danish Academic History.” Storia della Storiografica 5, no. 53 (2008): 97-110.

Nocera, Joe. "Down with Shareholder Value.” New York Times August 10, 2012.

Peck, Don. "Can the Middle Class Be Saved?" The Atlantic September, 2011.

U.S. Senate Committee on Banking and Currency. "The Pecora Report. The 1934 Report on the Practices of Stock Exchanges from the "Pecora Commission." Washington: US Senate Committee on Banking and Currency, 1934.

Philippon, Thomas. "Finance vs. Wal-Mart: Why Are Financial Services So Expensive?" In Rethinking the Financial Crisis, edited by Alan Blinder, Andrew Lo and Robert Solow, 235-46: New York, NY: Russell Sage, 2012.

Philippon, Thomas, and Ariell Reshef. "An International Look at the Growth of Modern Finance.” Journal of Economic Perspectives 27, no. 2 (2013): 73-96.

Piketty, Thomas, and Emmanuel Saez. "Inequality in the Long Run." Science 344, no. 6186 (2014): 838-43. 
Rangvid, Jesper. "Den Finansielle Krise I Danmark - Årsager, Konsekvenser Og Læring.” København: Økonomi-og Vækstministeriet, 2013.

Revell, Jack. "The Complementary Nature of Competition and Regulation in the Financial Sector." In Uk Banking Supervision. Evolution, Practice and Issues, edited by Edward P.M. Gardener, 161-81. London: Allen \& Unwin, 1986.

Schwartz, Anna. "Real and Pseudo Financial Crises." In Financial Crises and the World Banking System, edited by Forrest Capie and Geoffrey Wood, 11-31. New York: St. Martin's Press, 1986.

Shiller, Robert J. "The Best, Brightest, and Least Productive?" Project Syndicate September 2013. http://www.project-syndicate.org/print/ the-rent-seeking-problem-in-contemporary-finance-by-robert-j--shiller . "The Sickness beneath the Slump." New York Times June 11, 2011.

Sklansky, Jeffrey. "Labor, Money, and the Financial Turn in the History of Capitalism." Labor: Studies in Working-Class History of the Americas 11, no. 1 (2014): 23-46.

Stigler, George. "The Theory of Economic Regulation.” Bell Journal of Economics and Management Science 2, no. 1 (1971): 3-21.

Straarup, Peter. "Finansielle kriser. Hvad har den finansielle sektor lært af 90'erne." In Finansielle kriser - hvordan opstår de - Hvordan kan de bekæmpes. Finanstilsynet, 2006 https://www.finanstilsynet.dk/da/Om-os/ Taler-og-artikler/Andet/Konference-12-september-2006-Finansielle.aspx. Accessed July 22, 2014.

Uchitelle, Louis. "The Richest of the Rich, Proud of a New Gilded Age." New York Times 15 July 2007, 1, 18-9.

Wade, Robert. "From Global Imbalances to Global Reorganisations." Cambridge Journal of Economics 33 no. 4 (2009): 539-62.

White, Lawrence. "How Did We Get into This Financial Mess?" Cato Institute Briefing Papers no. 110 (2008).

\section{Films}

Capra, Frank. "It's a Wonderful Life." 1946.

Chandor, Jeffrey C. "Margin Call.” 2011.

Hanson, Curtis. "Too Big to Fail.” 99, 2011.

Jarecki, Nicholas. “Arbitrage.” 2012.

Jewison, Norman. “Other People’s Money.” 1991.

Johnson, Nunnally. "The Man in the Gray Flannel Suit.” 1956.

Jordan, Glenn. "Barbarians at the Gate." 1993.

Marshall, Garry. "Pretty Woman.” 1990.

Stone, Oliver. "Wall Street." 1987.

Wells, John. "The Company Men." 2010.

Wilder, Billy. "The Apartment." 1960.

Wise, Robert. "Executive Suite.” 1953. 